\title{
Impact of Financial Liberalization on Economic Growth: A Case Study of South Africa
}

Chipote Precious

200808258@ufh.ac.za

\section{Mgxekwa Bahle}

bmgxekwa@ufh.ac.za

\section{Godza Praise}

University of Fort Hare, Department of Economics, East London Campus, 50 Church Street, Private Bag X 9083, East London, 5200, South Africa

\section{Doi:10.5901/mjss.2014.v5n23p238}

\section{Abstract}

Financial liberalization plays a major role in stimulating economic growth. In light of this, the paper examines the impact of financial liberalization on macroeconomic performance in South Africa by using time series econometric analysis over the time period 1990-2011. The study uses GDP, the dependent variable as a measure of economic growth and the following macroeconomic variables: inflation, lending rate exchange rate and financial deepening (M2/GDP) as financial liberalization indices. To confirm the order of integration, the Augmented Dickey-Fuller and Phillips Perron unit root tests are employed. The study uses the Johansen co-integration and the Error Correction Mechanism to obtain long run and short run coefficients. Findings of the study are that inflation, lending rate and financial deepening have positive influence on economic growth whilst exchange rate has a negative impact on economic growth. This study recommends that the government should put in place measures that stimulate investments with fair lending rates so as to deepen the financial system which in turn promotes economic growth.

Keywords: Financial Liberalization, Economic Growth, Vector Error Correction Model, South Africa.

\section{Introduction}

Due to the widely spread benefits attainable from financial liberalisation as proposed by MacKinnon (1973) and Shaw (1973), many developing countries have experienced the gradual but apparent liberalisation of their financial sectors. Financial liberalization has become an important economic policy package in both advanced and advancing countries.

There are many definitions of financial liberalization and one such definition as proposed by Johnston and Sundararajan (1999) that financial liberalisation can be viewed as a set of operational reforms and policy measures designed to deregulate and transform the financial system and its structure with the view to achieving a liberalised market-oriented system within an appropriate regulatory framework. Financial liberalisation can take many forms such as deregulating interest rates, eliminating or reducing credit controls, allowing free entry into the banking sector, giving autonomy to commercial banks, permitting private ownership of banks, and liberalising international capital flows.

Although there is vast literature concerning the effects of financial liberalisation on economic growth, there lacks consensus as to the likely effects. Both McKinnon and Shaw advocated that financial liberalisation was needed as a remedy to the problems caused by the financial repressive policies of developing countries. Also other proponents of financial liberalisation support that it generates economic growth. Advocates for financial liberalisation argue that it leads to unlimited international capital flows thereby lowering the cost of capital, which allows for risk diversification. This in turn encourages investments in projects with higher returns, hence sustainable economic growth. On the other hand, opponents of financial liberalisation argue that it increases the risk of speculative attacks and increases a country's exposure to international shocks and capital flight which is harmful to economic growth. Other studies have altogether failed to establish the relationship between financial liberalisation and economic growth stating that it may be sensitive to a country's level of financial development. It is in light on these arguments that this study seeks to assess the impact of financial liberalisation on economic growth in the South African economy for the period 1990-2011. Based on the findings of the study, policies will be proposed which helps boost economic growth. 
The rest of the paper is outlined as follows: - section two gives an overview of financial liberalisation in the South African economy, section three reviews various related literatures and section four discusses the methodology. Section five presents the data analysis and interpretation of findings and section six provides conclusion, and recommendations

\section{Overview of Financial Liberalisation in South Africa}

Since the 1980s, there has been an ongoing liberalization of the financial system in South Africa. Interest and credit controls were removed in 1980, while liquidity ratios of banks were reduced substantially between 1983 and 1985. Credit ceilings were abolished in 1980. However capital and foreign exchange controls were still maintained in the 1980s. Exchange controls on non-residents were eliminated and those on households relaxed in 1995 allowing them full access to the Johannesburg Stock Exchange (JSE) Securities Exchange and the South African Bond Exchange (SABE) (Williamson and Mohar 1998).

South Africa's financial system is generally recognized as highly developed and sophisticated in comparison to other developing countries as well as to international standards. This is attributed to its skilled workforce, adequate capital resources, infrastructure and technology, and a conducive operating, regulatory and supervisory environment (NEDLAC, 2002). The Johannesburg Stock Exchange is ranked as the 18th largest stock exchange in the world in terms of market capitalization (Bureau of African Affairs 2000). The South African Reserve Bank (SARB) guides interest rates, and controls liquidity through the interest rates on funds provided to the private banks. By 1997, South Africa had about 51 licensed banks. In addition, there were five mutual (or community) banks. Out of the 51 licensed banks, eight were branches of foreign banks, while 11 were subsidiaries of foreign banks. Today, there are about 60 banks in South Africa, including 13 branches of foreign banks, and four mutual banks.

As previously mentioned South Africa liberalized both its lending and deposit rates in 1980. Prior to this, the South African Reserve Bank was responsible for determining maximum and minimum deposit and lending rates. The justification for interest rate liberalization was to allow banks greater flexibility and to encourage competition. In contrast to the expectations of the monetary authorities, interest rates remained negative in real terms after liberalization and only remained fairly and steadily positive over and above inflation, except in 1992.

The majority of the liberalisation process had emerged in South Africa after the lifting of international sanctions. By the end of 1992, most of the economic sanctions on South Africa were lifted. The liberalisation of the stock market which entails the removal of controls in the stock market emerged in the South African economy after the lifting on international sanctions. The liberalisation of the stock market is argued to lower the cost of equity capital by Bekaert and Harvey (2003), Stulz (1990). The plausible explanation for this finding is provided by Henry (2000), who argues that the liberalisation of the stock market provides a basis for risk sharing between domestic and foreign agents.

A harmonized liberalisation of the stock markets, capital account, banking sector and interest rate constitutes financial liberalisation. Starting from March 1995, several exchange control relaxations were effected. In March of 1997 and 1998 further controls were eased which permitted South African corporations to repatriate more funds for investment, and at the same time, domestic firms were permitted to borrow from abroad, the limit in foreign investment was later increased in March 2001. The South African interest rates were previously controlled between 1960s and 1970s like other financial prices. In 1970, the upper limits imposed on deposit rates payable on banks and deposits of building societies were dropped and the government later decided to subsidize certain interest rates. In 1972 these controls were reintroduced, however in 1980 South Africa liberalised both its lending and deposit rates to allow banks greater flexibility and to encourage competition.

\section{Literature Review}

The theory of financial liberalization is greatly explained by the works of MacKinnon (1973) and Shaw (1973). Financial liberalization refers to the removal of government ceilings on interest rates and of other controls on financial intermediaries. It is concerned with macroeconomic aggregates (interest rates, savings and investment) and conditions in formal financial markets (Baden, 1996). It refers to the removal of all constraints in the financial sector. In contrast, financial repression refers to distortions of financial prices such as interest rates. McKinnon (1973) and Shaw (1973) argue that liberalization enhances growth in an economy by allowing domestic and international firms to access their financial markets, and by improving the efficiency and corporate governance in domestic financial systems. Through financial liberalization, it is expected that real interest rates will higher which stimulates stimulate savings as consumers forgoes current consumption in favour of future consumption. This releases more funds for investments thereby leading to higher economic growth.

Paudel and Perera (2008) examined the role of financial liberalization on money demand and economic growth 
using autoregressive distributed lag (ARDL) approach of cointegration in Sri Lanka data for the period 1963 to 2006 . The study did not find a significant positive contribution of financial liberalization in money demand and economic growth of Sri Lanka. In the case of economic growth financial liberalization has played a positive role but not significant, while in the short-run the relationship is found to be negative.

Nyawata and Bird (1999) also assessed financial liberalization in SADC countries and concluded that for financial liberalization to be successful in promoting economic growth, it has to be placed within the context of other supporting policies. In the absence of such policies, the impact of financial liberalization is likely to be relatively insignificant, thereby generating neither the economic success nor failure.

McLean and Shresta (2002) did a study on international financial liberalisation and economic growth. Their empirical analysis employed annual data for a set of 40 countries, consisting of 20 developed and 20 emerging and developing countries in Asia, Latin America and Africa. The sample period covered the period 1976 to 1995 . They investigated the link between international financial integration and economic growth. They examined this issue with a particular emphasis on the composition of capital flows. They found that foreign direct investment and portfolio inflows enhance growth. By contrast, bank inflows appeared to have a negative effect on growth.

Baliomoune-Lutz (2003) conducted a study on financial liberalisation and economic growth in Morocco: A test of the supply- leading hypothesis. His study developed a vector error correction model (VECM) to explore the linkage between economic growth and financial liberalisation in Morocco using annual data for the period 1972 to 1999 . Their results provided support for the demand following view of the financial reforms that is economic growth leads finance. Contrary to the widely held stance the study did not find strong evidence in favour of the supply leading view of financial development that is financial development causes economic growth. For the South African economy, Tswamuno, Pardee and Wunnava (2007) concluded that liberalisation of the capital account is necessary but not sufficient for economic growth.

Oladipo (2010) examined the impact of trade liberalization (openness) on long run economic growth in Mexico using data from 1980-2008. Cointegration and error correction methods were employed. The empirical results suggest that long run economic growth in Mexico is largely explained by trade liberalization (openness) and the level of capital (investment). The contribution of labor force and human capital was found to be minimal.

For the economy of Ghana, Adam (2011) found a positive long run relationship between financial liberalisation and economic growth. Annually Standard of Living Index (SLI) from 1970-2007 was derived in the process using different policy measure and components. The financial liberalisation index was constructed using the Principal Component Analysis (PCA).Techniques employed in the study include the Johansen cointegration approach as well as the Granger causality test.

Odhiambo (2011) investigated on the impact of financial liberalisation in developing countries with specific reference to Zambia, South Africa, Tanzania and Lesotho. Findings of the study show that although financial liberalisation leads to financial development in all the study countries, it Granger-causes economic growth only in Zambia and in the other countries, it is the economic growth which induces the development of the financial sector. The results show that the relationship between financial liberalisation and economic growth is at best ambiguous, and may be sensitive to a country's level of financial development

Akingunola et al (2013) examined the relationship between financial liberalisation and economic growth in Nigeria and found out that monetary policies as well as financial development does not impact significantly on the growth process of the Nigerian economy both at the 5 percent and 1 percent level of significance. The financial liberalisation development was proxied by ratio of liquidity that is liabilities to GDP, real interest rate, and total deposit while the economic growth was measured by the real GDP.

Hye and Wizarat (2013) examined the impact of financial liberalisation on economic growth in Pakistan for the period 1971-2007. The Auto-Regressive Distributed Lag (ARDL) technique and a financial liberalisation index (FLI) developed by Hye and Wizarat (2010) were used. It was concluded that whereas there was a positive relationship between FLI and economic growth in the short run, FLI was statistically insignificant in the long run. It was however concluded that the impact of real interest rate (RIR) on economic growth is negative and significant in the long run.

\section{Methodology}

The existence of a short run and long equilibrium relationship among variables is established by employing various econometrics techniques such as Augmented Dickey-Fuller (ADF) and Phillips Perron Unit Root tests, Johansen Cointegration test and the Vector Error Correction Mechanism (VECM). The model employed in this study is built based on the modification of the models in Sulaiman (2012). 


\subsection{Model Specification and Definition of Variables}

The model specifies the endogenous variable (Gross Domestic Product) as a function of Inflation, Lending Rate, Exchange Rate, and Financial Deepening representing the exogenous variables. The model is specified as follows:

$G D P=f(I N F, L E N D, R E E R, F D)$

Where;

GDP = Gross Domestic Product measured as growth percentage and it is based on the annualized percentage change in the seasonally adjusted quarterly gross domestic product by industry at constant 2000 prices.

INF = Inflation rate as measured by the consumer price index (CPI) excluding food and non-alcoholic beverages for all urban areas. The CPI price index reflects the annual percentage change in the cost to the average consumer of acquiring a basket of goods and services that may be fixed or changed at specified intervals, such as yearly

LEND = Lending Rate. The rate charged by banks on loans to prime customers is used in this study.

REER = Real Effective Exchange Rate measured as average value of bilateral exchange rates for the period with respect to 15 trading partners, weighted by volume of trade in manufactured goods between South Africa and these countries.

FD= Financial Deepening calculated as M2 divided by GDP

$f=$ functional relationship

The econometric form of equation (1) above is represented as:

$G D P_{t}=\beta_{0}+\beta_{1} I N F_{t}+\beta_{2} L E N D_{t}+\beta_{3} R E E R_{t}+\beta_{4} F D_{t}+e$

Where:

$\beta_{0}=$ Intercept of relationship in the model/constant

$\beta_{0}-\beta_{4}=$ Coefficients of each independent or explanatory variable

$\mathrm{e}=$ Stochastic or Error term

\subsection{Data Sources}

The study gathered time series annual data for the above variables for the period covering 1990 to 2011 from the World Bank Statistic and the Reserve Bank of South Africa Statistics.

\section{Data Analysis and Interpretation of Findings}

\subsection{Unit Root Test}

There is need to conduct stationarity tests prior to the implementation of the Johansen co-integration technique. Data is tested for stationarity so as to avoid the problem of spurious regression. This study will employ the Augmented DickeyFuller (ADF) and Phillip-Perron test (PP) unit root tests to check the stationarity of the variables. Both tests test the null hypothesis of a unit root and the null hypothesis of a unit root is rejected in favor of the stationary alternative in each case if the test statistic is more negative than the critical value. Table 1 presents results of the unit root tests. Results of the unit root tests indicate that when considering the ADF test, the variable GDP is stationary at level series. The variables CPI, LEND and REER are however not stationary at level series and becomes stationary after first difference. The variable FD is still not stationary at both level and first difference. When considering the PP unit root test, all variables are stationary after first difference except for the variable GDP which is stationary at level series. Brooks (2008) explains that the PP test is more preferred over ADF tests due to various reasons. Consequently, it can therefore be concluded that according to the stricter PP test, variables are integrated of the order 0 and 1 in this study.

Table 1: Unit root tests 2000Q1-20010Q4 at levels and first differences $(\Delta)$

\begin{tabular}{|c|c|c|c|c|c|}
\hline & GDP & $\mathrm{CPI}$ & LEND & REER & FD \\
\hline \multicolumn{6}{|c|}{ ADF } \\
\hline Level & $-4.001964^{\star \star \star}$ & -2.681832 & -1.765158 & -2.177547 & -0.449009 \\
\hline First Difference & & $-4.280102^{\star * *}$ & $-4.064885^{\star * \star}$ & $-2.858444^{*}$ & -2.480675 \\
\hline \multicolumn{6}{|c|}{ PP } \\
\hline Level & $-3.901748^{\star * *}$ & -2.36928 & -1.319626 & -1.793688 & -0.827505 \\
\hline First Difference & & $-5.844652^{* * *}$ & $-4.175486^{* * *}$ & $-4.768084^{* * *}$ & $-10.31447^{* * *}$ \\
\hline
\end{tabular}




\subsection{Co integration Analysis Result and Interpretation}

Having established the order of co-integration, it is now possible to estimate the long and short run relationships using the Johansen co-integration technique. The technique requires that the optimums lag length, the appropriate model regarding the deterministic components in the multivariate system and the numbers of co-integrating vectors be specified before establishing long and short run relationships. Table 2 below shows results of optimum lag length selection. Results indicate that LR, FPE and HQ tests selected 5 lags whilst the AIC and SC selected 1 and 2 lags. The Johansen cointegration test is performed using 2 lags in this study as argued by Brooks (2008) that when choosing the optimum number of lags using the information criteria, the chosen number of lags is that number minimizing the value of the given information criterion.

Table 2: VAR leg length selection criteria

\begin{tabular}{|c|c|c|c|c|c|c|}
\hline Lag & LogL & LR & FPE & AIC & SC & $\mathrm{HQ}$ \\
\hline 0 & -1012.936 & NA & 23090.81 & 24.23657 & 24.38126 & 24.29473 \\
\hline 1 & -459.7430 & 1027.358 & 0.079849 & 11.66055 & 12.52870 & 12.00954 \\
\hline 2 & -394.8524 & 112.7861 & 0.031084 & 10.71077 & $12.30238 *$ & 11.35058 \\
\hline 3 & -373.9688 & 33.81166 & 0.034838 & 10.80878 & 13.12384 & 11.73942 \\
\hline 4 & -354.5457 & 29.13459 & 0.041020 & 10.94156 & 13.98009 & 12.16302 \\
\hline 5 & -281.2599 & $101.2043^{*}$ & $0.013670^{*}$ & 9.791901 & 13.55388 & 11.30419* \\
\hline 6 & -257.1936 & 30.36934 & 0.015108 & 9.814133 & 14.29957 & 11.61724 \\
\hline 7 & -228.3892 & 32.91932 & 0.015451 & $9.723552^{*}$ & 14.93245 & 11.81748 \\
\hline 8 & -205.1698 & 23.77225 & 0.018896 & 9.765947 & 15.69830 & 12.15070 \\
\hline \multicolumn{7}{|c|}{$\begin{array}{l}\text { * indicates lag order selected by the criterion } \\
\text { LR: sequential modified LR test statistic (each test at } 5 \% \text { level) } \\
\text { FPE: Final prediction error } \\
\text { AIC: Akaike information criterion } \\
\text { SC: Schwarz information criterion } \\
\text { HQ: Hannan-Quinn information criterion }\end{array}$} \\
\hline
\end{tabular}

The assumption of no deterministic trend and restricted constant was used for all the variables in the study. Tables 3 and 4 below present results for both trace test and maximum eigenvalue for unrestricted co-integration rank test respectively. Results from the Johansen cointegration trace test indicate that there is 1 co-integrating equation at $5 \%$ significance level. The null hypothesis of no co-integrating vectors is rejected since the trace (test) statistic of 74.83707 is greater than the critical value of 69.81889 at $5 \%$ significance level. Likewise, the maximum eigenvalue test also indicates that there is 1 co-integrating equation at $5 \%$ significance level. The null hypothesis of no co-integrating vectors is rejected since the maximum eigenvalue (test) statistic of 35.89072 is greater than the critical value of 33.87687 at $5 \%$ significance level. Thus 1 co-integrating equation is used for the study according to both tests.

Table 3: Cointegration Rank Test (Trace)

\begin{tabular}{|c|c|c|c|c|}
\hline Hypothesised No of CE(s) & Eigenvalue & Trace Statistic & 0.05 Critical value & Prob** \\
\hline None $^{*}$ & 0.331866 & 74.83707 & 69.81889 & 0.0188 \\
\hline At most $1^{*}$ & 0.209240 & 38.94636 & 47.85613 & 0.2624 \\
\hline At most 2 & 0.102388 & 18.05266 & 29.79707 & 0.5622 \\
\hline At most 3 & 0.087525 & 8.439073 & 15.49471 & 0.4197 \\
\hline At most 4 & 0.003221 & 0.287133 & 3.841466 & 0.5921 \\
\hline
\end{tabular}


Table 4: Cointegration Rank Test (Maximum Eigenvalue)

\begin{tabular}{|c|c|c|c|c|}
\hline Hypothesised No of CE(s) & Eigenvalue & Max-Eigen Statistic & 0.05 Critical Value & Prob** \\
\hline None $^{*}$ & 0.331866 & 35.89072 & 33.87687 & 0.0284 \\
\hline At most 1 & 0.209240 & 20.89370 & 27.58434 & 0.2827 \\
\hline At most 2 & 0.102388 & 9.613585 & 21.13162 & 0.7801 \\
\hline At most 3 & 0.087525 & 8.151940 & 14.26460 & 0.3635 \\
\hline At most 4 & 0.003221 & 0.287133 & 3.841466 & 0.5921 \\
\hline
\end{tabular}

\subsection{Vector Error Correction Model}

A vector error correction model (VECM) is used to disaggregate the long and short run effects. Table 5 below presents results of long run relationships.

Table 5: Results of long run relationship model of the variables

Dependent: GDP

\begin{tabular}{|c|c|c|c|}
\hline Variable & Coefficient & Std. Error & t-Statistic \\
\hline C & -6.232978 & & \\
\hline CPI(-1) & 0.551135 & 0.08777 & 6.27927 \\
\hline \hline LEND(-1) & 0.115348 & 0.12103 & 0.95303 \\
\hline REER(-1) & -0.034423 & 0.02448 & -1.40605 \\
\hline FD(-1) & 0.753465 & 0.40212 & 1.87374 \\
\hline
\end{tabular}

Results from Table 5 show that the long run co-integrating equation will be as follows:

$G D P_{t}=-6.23298+0.55114 C P I_{t}+0.11535 L_{E N D_{t}}-0.03442$ REER $_{t}+0.75347 F D_{t}+\mu \ldots \ldots . .(5.1$

From the equation, if all independent variables are held constant, GDP will reduce by 6.23298 units in the long run. The coefficient of $\mathrm{CPI}$ is 0.55114 , implying a positive relationship between $\mathrm{CPI}$ and GDP on the long run. $\mathrm{A}$ unit increase in CPI will cause a rise in GDP by 0.55114 units. The t-value of 6.27927 shows that CPI is significant in explaining modifications to GDP. The coefficient of LEND is 0.115348 . The coefficient is positively signed showing that in the long run, LEND and GDP are positively related. GDP will increase in the long run by 0.115348 units if LEND increases by a unit. The t-statistic of 0.95303 shows that LEND is statistically insignificant in determining changes in GDP.

REER has an inverse relationship with GDP. The results in Table 4 suggest that a unit increase in REER decreases GDP by approximately $3.44 \%$. The absolute t- value of 1.40605 indicates that exchange rate is insignificant in explaining changes in economic growth. This is in line with expected priori. The coefficient of FD is 0.753465 . The positively signed coefficient signifies that FD and GDP have a positive long run relationship. A unit increase in FD (M2/GDP) means that GDP will increase by $75.35 \%$. FD is statistically insignificant in explaining changes in GDP and this contrasts expected priori.

\subsection{Short-Run Analysis: An Error-Correction Model}

The error correction mechanism is the speed or degree of adjustment i.e. the rate at which the dependent variable adjust to changes in the independent variables. Table 5 below show the results of the short run vector error correction model.

Table 6: Results of short run relationship model of the variables

\begin{tabular}{|c|c|c|c|}
\hline Variable & Coefficient & Std. Error & t-Statistic \\
\hline $\mathrm{D}(\mathrm{GDP})$ & -0.692029 & 0.14332 & -4.82841 \\
\hline $\mathrm{D}(\mathrm{CPI})$ & -0.081579 & 0.09467 & -0.86171 \\
\hline $\mathrm{D}($ LEND) & 0.008801 & 0.03635 & 0.24213 \\
\hline $\mathrm{D}(\mathrm{REER})$ & 0.314317 & 0.16803 & 1.87061 \\
\hline $\mathrm{D}(\mathrm{FD})$ & 0.013142 & 0.00520 & 2.52487 \\
\hline
\end{tabular}


The negative coefficient of the Error Correction Mechanism implies that there is a feedback mechanism in the short run. The error correction helps to correct any disequilibrium in the short run. The variables GDP and CPI have negative coefficients showing that these variables converge to their long-run equilibrium. However the variables LEND, REER and FD have a positive coefficient indicating that any disequilibrium in them continues to grow. The coefficient of GDP is approximately -0.692029 implying that the speed of adjustment is around $69.21 \%$. This indicates that if there is a deviation from equilibrium, $69.21 \%$ is corrected in one quarter as the variable moves towards restoring equilibrium. The speed of adjustment is statistically significant with a t-value of 4.82841 .

\section{Conclusion and Recommendations}

The study examined the impact of financial liberalisation on macroeconomic performance in South Africa and economic growth. An overview of financial liberalisation in South Africa was discussed on when liberalisation was initiated, the development that occurred since it started and where the South African financial system is standing today. A review of literature was done and MacKinnon (1973) and Shaw (1973) theory of financial liberalisation was considered in this study. Most of the empirical literature reviewed advocate for a wise coordination between liberalization of the capital account and reforms aimed at strengthening the real sector of the economy. Most studies argue that liberalization of the capital account should follow that of the domestic financial system and the current account together with stabilization of the local macro-economy. Governments are encouraged to develop strong institutions for management of monetary policy and exchange rates before liberalization. This is because high capital mobility resulting from liberalization strongly affects the effectiveness of different instruments meant to achieve monetary policy objectives.

An analysis of data was performed using the outlined methodology. The results showed that in the long run inflation, lending rate and financial deepening have a positive relationship with economic growth while the exchange rate has a negative relationship with economic growth. All the variables except inflation were statistically insignificant in explaining economic growth.

Since the results showed a negative relationship between economic growth and exchange rate the best policy for South Africa is to leave the determination of exchange rates to the forces of demand and supply, where the rand exchange reverts to its own equilibrium. An inflation targeting policy adopted in February, 2000, should also continue to be effectively managed to keep inflation between $3 \%$ and $6 \%$ to avoid a large increases in inflation. Also measures that stimulate investments should be put in place with fair lending rates so as to deepen the financial system of South Africa which will promote economic growth.

\section{References}

Adam, M.A. (2011), Financial Openness Induced Growth and Poverty Reduction. The International Journal of Applied Economics and Finance, 5(1), 75-86

Akingunola, R.O., Olusegun, A.A., Oluwaseyi, B., and Olusoji, S.G. (2013). The Effect of the Financial Liberalisation on Economic Growth. International Journal of Academic Research in Economics and Management Sciences January, Vol. 2, No. 1: 2226-3624

Baden, S., (1996). Gender Issues in Financial Liberalization and Financial Sector Reform. Topic paper for Directorate General for Development, European Commission. BRIDGE Report No 39. Brighton: Institute of Development Studies

Baliamoune-Lutz, N. (2003). Financial Liberalisation and economic growth in Morocco: A test of the supply-leading hypothesis.

Bekaert, G., and Harvey, C.R. (2003). Emerging markets finance. Journal of Empirical Finance 10:3 - 55.

Brooks, C. (2008) "Econometrics for Finance" 2nd Edition. Cambridge University Press.

Bureau of African Affairs. (2000). Country information. US State Department, April.

Henry, P.B., (2000). Stock market liberalization, economic reform and emerging market equity prices. Journal of Finance 55 (2), 529 564.

Hye, Q. M. A., and Wizarat, S. (2013). Impact of Financial Liberalization on Economic Growth: A Case Study of Pakistan. Asian Economic and Financial Review.

Hye, Q.M.A., and Wizarat, S. (2010). Financial liberalization index for Pakistan. International Review of Applied Financial Issues and Economics, Forth coming issue.

Johnston, R.B and Sandararajan, V. (1999). Sequencing Financial Sector Reforms, Country Experiences and Issues. International Monetary Fund, Washington D.C Journal of Financial Economics 77 (1), 3-55.

McLean, B., and Shresta, S. (2002). International Financial Liberalisation and Economic Growth. Research Discussion Paper: Economic Research Department Reserve Bank of Australia, January.

Mckinnon, R.I. (1973). Money, Capital and Banking in Economic Development. Brooklyn Institution, Washington D.C

Nyawata, O., and Bird, G. (2004). Financial Liberalization in Southern Africa: An Assessment. Development Policy Review, 22 (3): 287307 
Odhiambo, N.M., (2011). The impact of financial liberalisation in developing countries: experiences from four SADC countries. Organisation for Social Science Research in Eastern and Southern Africa (OSSREA), Addis Ababa.

Oladipo, O.S. (2010). Does Trade Liberalization Cause Long Run Economic Growth in Mexico? An Empirical Investigation. International Journal of Economics and Finance.1916-9728

Paudel, R. C., and Perera, N.(2008). How does Financial Liberalisation Impact on Money Demand and EconomicbGrowth? Evidence from Sri Lanka.

Shaw, E. (1973). Financial Deepening in Economic Development. Oxford University Press, New York.

Stulz, R. M., (1990). Managerial discretion and optimal financing policies, Journal of Financial Economics 26, 3-28

Sulaiman, L.A., Oke, M.O. and Azeez, B.A. (2012). effect of financial liberalization on economic growth in developing countries: The Nigerian Experience. International Journal of Economics and Management Sciences Vol. 1, No. 12, 2012, pp. 16-28

Tswamuno,D. T., Pardee,S. and Wunnava, P.V. (2007). Financial Liberalization and Economic Growth: Lessons from the South African Experience. International Journal of Applied Economics, 4(2), September 2007, 75-89 75

Williamson, J., and Mohar, M., (1998). A survey of Financial Liberalisation. Essays in International Finance, Princeton University, No. 211. 